\section{Cancer: The Significance of Delay}

Robert Sutherland, M.D., D.P.H. Pp. ix +206 + index. London: Butterworth. 1960. 30s.

In this book the author, who is the director of the British Empire Cancer Campaign (Yorkshire Council) Cancer Survey, attempts the colossal task of surveying all the literature relating to prognosis in cancer and drawing reasonable conclusions from this often conflicting material.

The book starts with a short introduction in which the problem is outlined. This is followed by a good chapter in which the author emphasizes the difficulties of his task; he points out that various writers use different criteria for diagnosis, classification of grade and stage of tumours, and for assessment of the effect of treatment, some even failing to define exactly the terms they were using. In this way much published material becomes unsuitable for a comparative study.

The next two chapters, which between them comprise more than half the book, deal with the bearing on prognosis of various characteristics of the tumour and the host. There is a short chapter on environmental influences, and a final section in which the author brings together the main points from the previous chapters and attempts to answer the question, 'Does delay in starting treatment affect prognosis in cancer?'

In a book which covers such a large field, some omissions are inevitable. These sometimes lead to over-simplification, as in Chapter III, where the impression is given that in gastric cancer a fairly close correlation exists between the degree of histological differentiation and prognosis. Many workers who have studied the problem have not found this to be so.

The text, liberally interspersed with tables, presents a somewhat forbidding appearance to the eye but, for the assistance of readers, the author has provided an excellent concise summary at the end of each chapter.

This is a most valuable book. It provides a fund of information, an excellent list of references, and represents the fruit of much work and thought. A sensible, unemotional discussion of this subject was badly needed, especially in view of recent work which has suggested that early treatment was of less importance than was formerly thought. This book more than supplies that need.

\section{Techniques of Thoracotomy}

B. T. Le RouX, M.B., CH.B., F.R.C.S.E. Pp. xi + 94, illustrated. Edinburgh and London: E. \&. S. Livingstone. 1961. 55 s.

This short book contains a detailed account of the methods which one thoracic surgical unit employ for opening and closing the thoracic cavity, a short chapter also being included with an account of drainage of empyema thoracis. Such a monograph is bound to be dogmatic and it is presumably directed at a particular group of readers. The general surgeon may derive some benefit from it, although many would quarrel with the exact description of thoracolaparotomy. The high price of this book is probably due to the large number of illustrations which demonstrate again that coloured photographs of bloodstained incisions add little to the clarity of verbal description.

\section{Recent Advances in Human Nutrition}

J. F. BROCK, D.M.(oXoN.), F.R.C.P., with a number of invited contributors. Pp. xii +454 , illustrated.

London: J. \& A."Churchill. r96r. 50 s.

This book is addressed to medical practitioners ând also to others concerned with nutrition. The emphaigis is clinical but no account of diets or practical therapeutics is given. It is divided into two parts.

In the first, Professor J. F. Brock gives a comprehensive review of modern trends. Written from Cape Town, this is a global survey of human nutrition in health disease. It is supported by numerous references to the recent literature and is a readable and balanced sughmary. Consideration of the commonest nutritional disorder in this country-overnutrition-is brief agd reflects the preoccupation with undernutrition elsewhere.

The second section, which comprises more than holf the book, is made up of 14 chapters written by invitation. The contributors are drawn from South Africa, the U.S.A., Germany, France, and the United Kingdoon. From London, B. S. Platt discusses protein values-of human foods and A. W. Woodruff nutritional anæmia. Other topics include nutrition in infancy and old age, kwashiorkor, relation of nutrition to infection, and influence of altered nutrition on the skeleton and endocrine glands.

This is a useful volume which amply measures fipto its title. The needs of the general physician and general reader are probably covered by the first part whinh includes a summary of the material in the second $\bar{p}$ art. The later chapters are more difficult to assess. Thy present a great deal of factual information but some sre difficult to read and they form rather a miscellany. ЭIt is perhaps unfortunate that the two parts have not beien published separately.

\section{A Short History of Clinical Pathology}

W. D. Foster, M.D. With a chapter on $\overrightarrow{\vec{B}_{e}}$ Organization of Clinical Pathology to the Present Day by S. C. DyKe, D.M., F.R.C.P. Pp. xii +1 , illustrated. Edinburgh and London: E. \&. क्वे. Livingstone. 1961. 27s. $6 d$.

Dr. W. D. Foster undertook a difficult task in writ a history of clinical pathology but he has done-it supremely well and produced a book which is interest and full of useful information. It was a difficult task because clinical pathology is a relatively new specianty and no one, in this country at any rate, has previougly attempted such a comprehensive and detailed historyoof the development of this subject.

It is a book which will be read with special interest by practising clinical pathologists and will come to regarded as an indispensable source of reference.

Dr. Foster was fortunate in being able to persuage Dr. S. C. Dyke to contribute a final chapter on the organization of clinical pathology to the present ofy because Dr. Dyke was the founder of the Association of Clinical Pathologists. This body came into existeme as the result of a letter from Dr. Dyke which was published in the British Medical fournal and Lancet in January 1927 , and during the past 30 years it has ben actively engaged in helping to improve the status? of clinical pathologists and in developing pathological services throughout this country. 